\title{
Effects of an angiotensin-converting enzyme inhibitor (captopril) on blood pressure in anephric subjects
}

\section{Summary and conclusions}

Randomised, double-blind cross-over trials were performed in seven anephric patients to determine the effect of the orally active angiotensin-converting enzyme inhibitor captopril on blood pressure in fluid-depleted and fluid-replete patients. Patients were given captopril, $100 \mathrm{mg}$ orally, or placebo one hour after haemodialysis, when they were fluid depleted. Their mean $( \pm$ SEM) supine blood pressure fell from $127 \pm 12 / 71 \pm 6 \mathrm{~mm} \mathrm{Hg}$ before captopril to $106 \pm 13 / 54 \pm 4 \mathrm{~mm} \mathrm{Hg} 24$ hours after the drug, while on placebo it rose from $123 \pm 11 / 73 \pm 5$ $\mathrm{mm} \mathrm{Hg}$ to $134 \pm 10 / 82 \pm 8 \mathrm{~mm} \mathrm{Hg}$. All patients developed orthostatic hypotension after captopril. In the fluidreplete state, two days after haemodialysis, captopril had no effect on blood pressure. The plasma concentration of active renin was extremely low and did not rise after fluid'withdrawal or'captopril. Thus the hypotensive effect of captopril did not appear to depend on circulating renin concentrations.

The concept of "renin-dependent" hypertension, which is responsive to captopril, as opposed to "volumedependent" hypertension, which is not responsive to captopril, may therefore be invalid.

\section{Introduction}

Peptidyldipeptide hydrolase, which converts angiotensin I into the potent vasoconstrictor angiotensin II (angiotensinconverting enzyme) and degrades the vasodilator bradykinin (kininase II), ${ }^{1}$ is inhibited by the orally active drug captopril (SQ 14225). ${ }^{2}$ Captopril's effectiveness as an antihypertensive agent has now been firmly established in both animals ${ }^{13-5}$ and man. ${ }^{6} 8$ The fall in arterial pressure after inhibition of the converting enzyme seems to be directly correlated with the pretreatment concentrations of circulating renin. ${ }^{9-11}$ It is therefore commonly believed that captopril lowers blood pressure mainly through its action on the renin-angiotensin system. ${ }^{6}{ }^{7}$ The greater fall in pressure after stimulation of the renal release of renin by sodium and water depletion seems to support this view. ${ }^{7-12}$ Captopril therefore seems to be a simple and useful tool for searching out those patients whose hypertension depends on overactivity of the renin-angiotensin system and who would benefit particularly from drugs that suppress this system. ${ }^{6} 91013$

Nevertheless, some data suggest that captopril given repeatedly over a period will lower blood pressure equally well in patients with low and normal renin concentrations. ${ }^{6-8}$ We describe here a study to determine the hypotensive effect of captopril in anephric subjects after they had been treated with ultrafiltration.

\footnotetext{
Department of Internal Medicine I, University Hospital Dijkzigt, Erasmus University, Rotterdam

ARIE J MAN IN 'T VELD, MD, research registrar

FRANS H M DERKX, MD, clinical pharmacologist

JAN H B DE BRUYN, MD, senior medical registrar

MAARTEN A D H SCHALEKAMP, MD, senior lecturer and consultant physician

Department of Internal Medicine, Division of Nephrology, University Hospital Leiden, the Netherlands

IEKE M SCHICHT, MD, consultant physician
}

\section{Patients and methods}

Seven anephric subjects (four men) aged 30 to 58 years who had been anephric for one to nine years participated in the study. All gave their informed consent to the study. The effects of captopril and placebo on blood pressure were first compared in a randomised, double-blind cross-over study when the patients were relatively fluid depleted. The patients underwent dialysis three times a week on a Rhodial-75 single-patient unit with a RP-6 disposable polyacrylonitryl membrane kidney. The recirculating dialysate contained $140 \mathrm{mmol}$ sodium per litre. The mean $( \pm$ SEM) loss of body weight per dialysis session was $1.8 \pm 0.2 \mathrm{~kg}$ on captopril and $2.0 \pm 0.2 \mathrm{~kg}$ on placebo, the difference being statistically insignificant (see table). Four patients were given captopril, $100 \mathrm{mg}$ orally, one hour after haemodialysis. The remaining three patients were given placebo, which was similar to the captopril tablet in taste, form, and colour. Two days later the patients who had been on captopril received placebo and vice versa, again one hour after haemodialysis. Blood pressure was measured at 15-minute intervals for two hours after the dose of captopril or placebo and again at 24 hours. It was recorded in duplicate by the same investigators (AJMV and IMS) using a London School of Hygiene sphygmomanometer (MK4, no 7125) to avoid observer bias and digit preference. Heart rate was computed from a continuous electrocardiographic (ECG) tracing.

One week later the patients underwent a second trial with captopril, $100 \mathrm{mg}$ orally, again in a double-blind fashion, two days after haemodialysis, when they were fluid replete. The effect of captopril on blood pressure was followed for two hours until the next dialysis session was started. Finally, captopril, $100 \mathrm{mg}$ orally, was given on a third occasion one day after haemodialysis, and its effect was assessed after 24 hours, just before the next dialysis session was started.

Enzymatically active plasma renin was measured by radioimmunoassay of angiotensin $I$, which was generated after incubation for three hours at $37^{\circ} \mathrm{C}$ and $\mathrm{pH} 7.5$ with an excess of purified sheep renin substrate. ${ }^{14}$ Results were expressed as $\mu \mathrm{U}$ of an international renin standard (MRC 68/356). The normal value in our laboratory is $15-40$ $\mu \mathrm{U} / \mathrm{ml}$. The converting enzyme activity of plasma was measured by the rate of production of hippuric acid from hippuryl-L-histidyl-Lleucine $^{15}$ and expressed as a percentage of the control value before captopril.

For statistical comparison of data we used Student's paired $t$ test. $P$ values less than 0.05 were considered to indicate statistically significant differences.

\section{Results}

In the fluid-depleted state one hour after haemodialysis body weight on captopril was not significantly different from that on placebo (see table). Supine blood pressure on placebo, which was given one hour after dialysis, did not change over a period of two hours, and after 24 hours it had significantly increased $(p<0.01$; fig 1$)$. In contrast, supine blood pressure fell with captopril and, 30-120 minutes after the drug had been given, blood pressure was significantly lower than on placebo. Two hours after placebo blood pressure did not change on standing for two minutes, but it fell after captopril $(p<0.05$; fig 2). Twenty-four hours after captopril had been given, all patients complained of dizziness and had overt orthostatic hypotension. Four of them nearly fainted on standing. There was no significant difference in supine heart rate between the captopril and placebo periods, and the increments of heart rate on standing were also the same (fig 2).

Figs 3 and 4 compare the effects of captopril on supine and standing blood pressures in the fluid-replete state with those after fluid withdrawal. Supine and standing blood pressures were higher in the fluidreplete state two days after haemodialysis and blood pressure did not fall after captopril. The orthostatic fall in blood pressure induced by 
Effect of captopril and placebo on active plasma renin and angiotensin-converting enzyme activity in fluid-depleted and fluid-replete states. Values are means \pm SEM

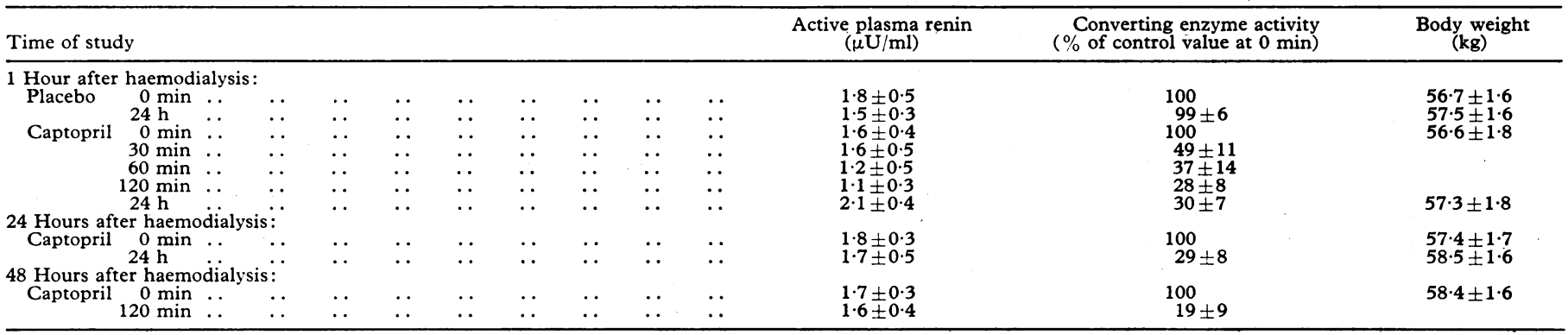

captopril in the fluid-depleted state was not observed after fluid repletion. The increments in heart rate on standing were similar before and after captopril in both fluid-depleted and fluid-replete states.

Active plasma renin concentrations were extremely low in all patients and did not respond to fluid withdrawal or to captopril (see table). As judged from measurements of converting enzyme activity in plasma, captopril was effective for at least 24 hours in our patients.

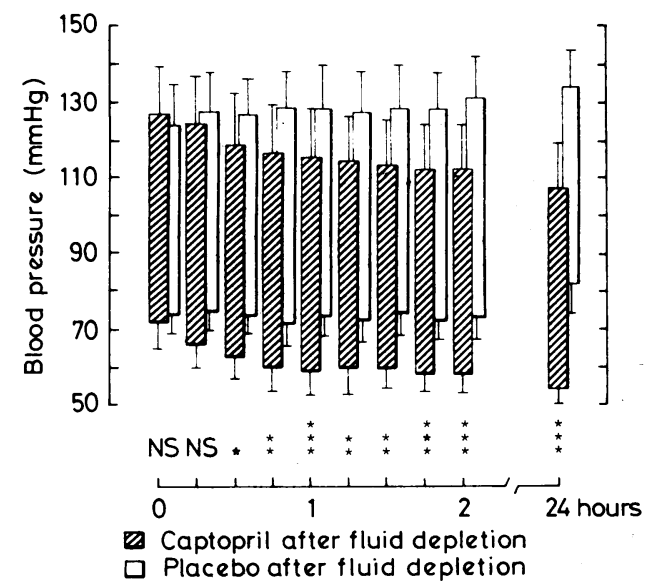

FIG 1 -Effect of captopril versus placebo on blood pressure in seven fluiddepleted anephric subjects. NS $=$ Not significant. $* P<0.05$. $* * P<0.01$ $* * * \mathrm{P}<0.001$.

\section{Discussion}

Our findings show that blood pressure can be greatly reduced in anephric subjects by captopril, an agent known to inhibit both the formation of angiotensin II and degradation of bradykinin. Since the main source of renin has been removed and plasma renin and angiotensin II concentrations are very low in these patients, ${ }^{16}$ it is unlikely that this effect depends on the circulating levels of these hormones. Blood pressure fell after captopril whenever the patients were not overloaded with fluid. A similar influence of fluid balance on the hypotensive response to angiotensinconverting enzyme inhibitors and angiotensin II antagonists has been observed in normotensive and hypertensive subjects who have not undergone nephrectomy. ${ }^{10-12} 1^{7}$ This is commonly taken as evidence that blood pressure becomes "renin dependent" when the release of renin is stimulated by sodium and water depletion. Our observations in anephric subjects, who had very low plasma renin concentrations which did not increase after fluid withdrawal, strongly suggest that factors unrelated to circulating renin are important for maintaining blood pressure after sodium and water depletion. The hypotensive effect of captopril is probably also not related to circulating bradykinin concentrations. Studies with the converting enzyme inhibitor teprotide (SQ 20 881) in man failed to show any effect on plasma bradykinin values. ${ }^{12} 18 \mathrm{~A}$ transient rise in plasma bradykinin after teprotide has been reported, ${ }^{19}{ }^{20}$ but the bradykinin values in that report were ten times higher than those in a more recent study which failed to show significant changes in plasma bradykinin in patients with essential hypertension treated with longterm captopril. ${ }^{21}$

Angiotensin-converting enzyme is present in the vascular endothelium ${ }^{22}$ and renin has been extracted from the arterial wall. ${ }^{23}{ }^{24} \mathrm{~A}$ physiological role for vascular renin in maintaining blood pressure in the hypertensive anephric rat has been recently put forward by Turston and Swales, ${ }^{25}$ who found that inhibition of converting enzyme resulted in a considerable fall in blood pressure one and two hours after nephrectomy, when plasma renin had already declined to insignificantly low values. Furthermore, plasma prekallikrein, which circulates as a complex with its substrate, high-molecular-weight. kininogen, is rapidly absorbed together with factor XII on negatively charged surfaces, such as collagen and vascular basement membrane. ${ }^{26}$ This leads to activation of factor XII and the local formation of kallikrein and possibly also bradykinin. Captopril may thus act in the blood-vessel wall or in close contact with it, rather than in the circulating blood.

Haemodynamically, captopril acts as a vasodilator with an important effect on the veins. ${ }^{27}{ }^{28}$ Venous dilatation will tend to reduce venous return to the heart and consequently cardiac output. This might explain why captopril caused orthostatic hypotension in our anephric patients when they were fluid depleted. It may be relevant that the rare syndrome of familial hyperbradykininism is characterised clinically by severe ortho-
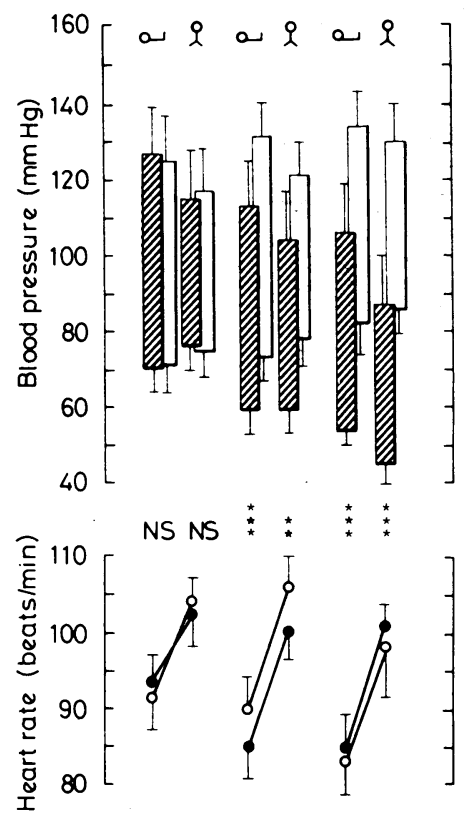

NS NS NS NS NS NS

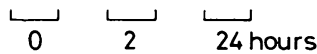

Captopril after fluid depletion Placebo after fluid depletion 
static hypotension. ${ }^{29}$ The enhancement of captopril's hypotensive effect by sodium and water depletion, which has also been observed in subjects who have not undergone nephrectomy, might be an indication of the importance of blood volume rather than plasma renin for maintaining blood pressure. Hypotension will not develop as long as "effective" blood volume and cardiac filling pressures are adequate. The alleged transition of so-called "volume-dependent" hypertension into "renin-dependent" hypertension after sodium and water depletion, for instance by diuretics, might therefore be an illusion rather than reality.

Whatever the underlying mechanism of captopril's hypotensive effect, our results lend further support to preliminary suggestions that this drug will be effective in the large group of hypertensive patients in whom plasma renin is not raised.

We thank Professor Dr J de Graeff, for giving us the opportunity to study the anephric patients in his department, and Dr P Piggott, of Squibb Europe, for supplies of captopril.

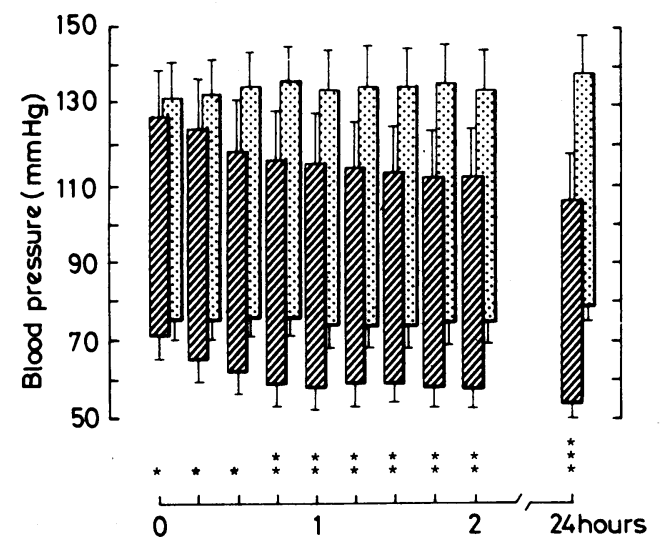

ש Captopril after fluid depletion

Captopril after fluid repletion

FIG 3-Effect of captopril in fluid-depleted and fluid-replete states on blood pressure in seven anephric subjects. See legend to fig 1 for statistical values.

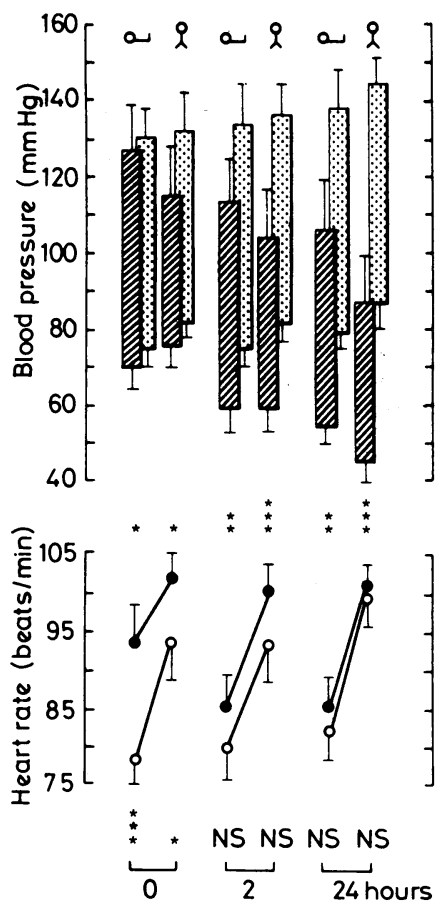

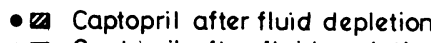

$\circ \otimes$ Captopril after fluid repletion

FIG 4-Effects of captopril in fluid-depleted and fluid-replete states on supine and standing blood pressure and heart rate in seven anephric subjects. See legend to fig 1 for statistical values.

\section{References}

1 Erdös EG. Angiotensin I converting enzyme. Circ Res $1975 ; 36: 247-55$.

2 Ondetti MA, Rubin B, Cushman DW. Design of specific inhibitors of angiotensin-converting enzyme: a new class of orally active antihypertensive agents. Science 1977;196:248-50.

${ }^{3}$ Laffan RJ, Goldberg ME, High JP, Schaeffer T, Waugh MH, Rubin B. Antihypertensive activity of SQ 14.225, an orally active inhibitor of angiotensin-converting enzyme. Fed Proc 1977;36:1049.

4 Rubin B, Antanaccio MJ, Goldberg ME, et al. Chronic anti-hypertensive effect of captopril (SQ 14.225), an orally active angiotensin I-converting enzyme inhibitor in conscious 2-kidney renal hypertensive rats. Eur $\mathcal{F}$ Pharmacol 1978;51:377-88.

${ }^{5}$ Rubin B, Antanaccio MJ, Horovitz ZP. Captopril (SQ 14.225) (D-3Mercapto-2-Methylpropanoyl-L-Proline). A novel orally active inhibitor of angiotensin-converting enzyme and anti-hypertensive agent. Prog Cardiovasc Dis 1978;21:183-94.

${ }^{6}$ Gavras H, Brunner HR, Turini GA, et al. Anti-hypertensive effect of the oral angiotensin-converting enzyme inhibitor SQ 14.225 in man. $N$ Engl $\mathcal{F}$ Med 1978;298:991-5.

7 Case DB, Atlas SA, Laragh JH, Sealey JE, Sullivan PA, McKinstrey DJ. Clinical experience with blockade of the renin-angiotensin-aldosterone system by an oral converting-enzyme inhibitor (SQ 14.225, captopril) in hypertensive patients. Prog Cardiovasc Dis 1978;21:195-206.

8 Brunner HR, Gavras H, Waeber B, et al. Oral angiotensin-converting enzyme inhibitor in long term treatment of hypertensive patients. Ann Intern Med 1979;90:19-23.

- Case DB, Wallace JM, Keim HJ, et al. Estimating renin participation in hypertension, superiority of converting enzyme inhibitor over saralasin. Am $\mathcal{F}$ Med 1976;61:790-6.

10 Case DB, Wallace JM, Keim JH, Weber MA, Sealey JE, Laragh JH. Possible role of renin in hypertension as suggested by renin-sodium profiling and inhibition of converting enzyme. $N$ Engl $\mathcal{f}$ Med 1977; 296 : $641-6$.

11 Gavras H, Ribeiro AB, Gavras I, Brunner HR. Reciprocal relation between renin dependency and sodium dependency in essential hypertension. $N$ Engl f Med 1976;295:1278-83.

12 Sancho J, Re R, Burton J, Barger AC, Haber E. The role of the reninangiotensin-aldosterone system in cardiovascular homeostasis in normal human subjects. Circulation 1976;53:400-5.

13 Brunner HR, Waeber B, Wauters JP, Turini G, McKinstry D, Gavras H. Inappropriate renin secretion unmasked by captopril (SQ 14.225) in hypertension of chronic renal failure. Lancet 1978;ii:704-7.

14 Derkx FHM, Wenting GJ, Man in 't Veld AJ, van Gool JMG, Verhoeven $\mathrm{RP}$, Schalekamp MADH. Inactive renin in human plasma. Lancet 1976;ii:496-9.

15 Cushman DW, Cheung HS. Spectrofotometric assay and properties of the angiotensin-converting enzyme of rabbit lung. Biochem Pharmacol 1971; 20:1637-48.

${ }^{16}$ Deheneffe J, Cuesta V, Briggs JD, et al. Response of aldosterone and blood pressure to angiotensin II infusion in anephric man. Effect of sodium deprivation. Circ Res 1976;39:183-90.

17 Brunner HR, Gavras H, Laragh JH, Keenan R. Angiotensin II blockade in man by Sar $^{1}-\mathrm{Ala}^{8}$-angiotensin II for understanding and treatment of high blood pressure. Lancet 1973;ii:1045-8.

18 Miller ED Jr, Samuels AI, Haber E, Barger CA. Inhibition of angiotensin conversion and prevention of renal hypertension. Am $\mathcal{F}$ Physiol $1975 ; 228: 448-53$.

19 Williams GH, Hollenberg NK. Accentuated vascular and endocrine responses to SQ 20.881 in hypertension. $N$ Engl F Med 1977;297:1848.

${ }^{20}$ Mersey JH, Williams GH, Hollenberg NK. Relationship between aldosterone and bradykinin. Circ Res $1977 ; 40$,suppl:84-8.

21 Johnston CI, Miller JA, McGrath BP, Matthews PG. Long-term effects of captopril (SQ 14.225) on blood-pressure and hormone levels in essential hypertension. Lancet 1979;ii:493-5.

${ }^{22}$ Ryan JW, Ryan US, Schultz E. Subcellular localisation of pulmonary angiotensin-converting enzyme (Kininase II). Biochem $\mathcal{F}$ 1975;146:4979.

${ }^{23}$ Gould AB, Skeggs LT, Kahn JR. The presence of renin activity in blood vessel walls. $\mathcal{f} \operatorname{Exp}$ Med 1964;119:348-9.

${ }^{24}$ Rosenthal J, Boucher R, Roja-Ortega JM, Genest J. Renin activity in aortic tissue of rats. Can $\mathcal{F}$ Physiol Pharmacol 1969;47:53-6.

25 Thurston $\mathrm{H}$, Swales JD. Blood-pressure response of nephrectomized hypertensive rats to converting enzyme inhibitor: evidence for persisting vascular renin activity. Clin Sci Mol Med 1977;53:299-304.

26 Ogston D, Bennett B. Surface-mediated reactions in the formation of thrombin, plasmin and kallikrein. Br Med Bull 1978;34:107-12.

27 Cody RJ, Tarazi RC, Bravo EL, Fouad FM. Haemodynamics of orally active converting enzyme inhibitor (SQ 14.225) in hypertensive patients. Clin Sci Mol Med 1978;55:453-9.

28 Turini GA, Brunner HR, Gribic M, Waeber B, Gavras H. Improvement of chronic congestive heart failure by oral captopril. Lancet 1979; : 1213-5.

29 Straeten DHP, Kerr LP, Kerr CB, Prior JC, Dalakos TG. Hyperbradykininism. A new orthostatic syndrome. Lancet 1972;ii:1048-53.

(Accepted 12 November 1979) 